\title{
Regional Histomorphometry of the Hepatic Inferior Vena Cava; a Possible Sphincteric Mechanism
}

\author{
Histomorfometría Regional de la Vena Cava Inferior Hepática; \\ un Posible Mecanismo de Esfínter
}

P. K., Bundi; J. A.,Ogeng'o; J. Hassanali \& P. O. Odula

BUNDI, P. K.; OGENG'O, J. A.; HASSANALI, J. \& ODULA, P. O. Regional histomorphometry of the hepatic inferior vena cava; a possible sphincteric mechanism. Int. J. Morphol., 27(3):849-854, 2009.

SUMMARY: This study was aimed at identifying the changes in diameter and structural composition of the Hepatic Inferior Vena Cava in its infrahepatic, intrahepatic and suprahepatic portions. Eighty adult liver specimens from the Chiromo and Nairobi City mortuaries were used for morphometry, while twenty of them were processed for light microscopy. A constriction was noted in the midportion of the HIVC, while structurally; the intrahepatic portion had thicker fibromuscular adventitia. It is plausible that these are sphincteric apparatus to prevent backflow of blood in the Hepatic Inferior Vena Cava.

KEY WORDS: Inferior vena cava; Hepatic; Sphincter; Backflow.

\section{INTRODUCTION}

The diameters of the lower and upper ends of the Hepatic Inferior Vena Cava have been studied (Sahni et al., 2006) with relatively little attention paid to the midportion. The diameter of the mid portion of the HIVC may be influenced by its hepatic course (whether in a complete tunnel or groove). Regional variations have been observed in the renal portion of the IVC, whereby the tunica adventitia becomes more muscular cranially (Medeiros de Mello et al., 1997). The tunica media has been reported as absent in some parts (Greep \& Weiss, 1973). No regional differences have been attributed to the tunica intima (Young $\&$ Heath, 2002). At the hepatic portion, there is increased pressure and resistance in the HIVC (Cheng et al., 2003). It is possible that there exist regional differences in the diameters and mural structure of the HIVC to ensure forward flow of blood amidst the hemodynamic challenges. This study set out to study the histomorphometry of the upper, mid and lower portions of the HIVC, in order to unravel adaptations to counter the hemodynamic forces generated by the liver and increased blood.

\section{MATERIAL AND METHOD}

Eighty adult liver specimens obtained from Nairobi City Mortuary and Depart of Human Anatomy, University of Nairobi, were used. All the eighty were used for morphometry. Twenty fresh specimens, less than 48 hours postmortem were used for histomorphology.

After entry into the abdominal cavity, the stomach and intestines were reflected to reach the porta hepatis. The liver along with the IVC from the junction with renal veins to the diaphragm was removed en block. Caudally, the IVC was divided transversely at the lower end of the posterior border of the caudate process and cranially where it pierced the diaphragm. The IVC was opened posteriorly by a vertical incision extending from the upper to lower ends. The length of the entire flaps was measured as the circumference using Namutan ${ }^{\circledR}$ vernier calipers (precision $0.02 \mathrm{~mm}$ ) and the diameter was calculated (by dividing the circumference by 3.142). This was done for upper, middle and lower ends. Data analysis was done using SPSS software (Version 15.0, Chicago, Illinois). The student's t-test was used for analyzing morphometric differences

Department of Human Anatomy, School of Medicine, the University of Nairobi, Kenya. 
between lower, mid and upper diameters. A p value of less than 0.05 was considered significant.

For histomorphology, serial $1 \mathrm{~cm}$ equidistant samples were taken from the infrahepatic, intrahepatic and suprahepatic portions of the HIVC as shown in Figure 1.

Five-millimeter thick sections were taken from the segments. Fixation of the tissue was done for three days using $10 \%$ formaldehyde solution. These segments were then dehydrated in ethyl alcohol of increasing concentrations, commencing with $70 \%$ ethanol to absolute alcohol. Trichloroethane was used as a clearing agent for 1.5 hours then wax impregnation and infiltration at $60^{\circ} \mathrm{c}$ for 12 hours. $7 \mathrm{~mm}$ thick sections were cut using a Lezlar® microtome (SM2400, Germany). Dewaxing was done using xylene, and the segments were rehydrated in xylol, absolute alcohol and descending grades of alcohol up to $70 \%$ (i.e. running to water). Masson's Trichrome was used to study the cytoarchitecture and connective tissue of the IVC wall (Bancroft et al, 1994). Weigert's resorcin fuschcin and van Gieson counterstaining was used to demonstrate elastic fibers. For microscopic analysis, a Leica ${ }^{\circledR}$ light microscope (BME model, Germany) was used. A digital camera (Olympus ${ }^{\circledR}, 6$ megapixels) was used to take photographs showing the mural structure of the HIVC.

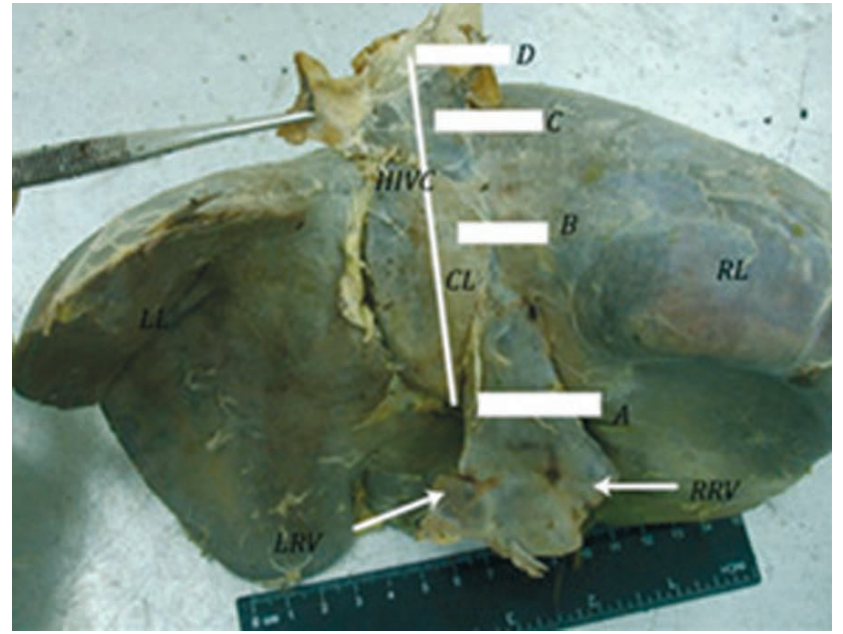

Fig. 1. Macrograph of the posterior surface of the liver showing the sites from which specimens for microscopy were taken. A (Infrahepatic), B (Intrahepatic), C (suprahepatic subphrenic) and $\mathrm{D}$ (suprahepatic phrenic). The near vertical line shows the extent of the HIVC. CL; Caudate lobe, RL; Right lobe, RRV; Right renal vein; LRV; Left renal vein and LL; Left lobe.

\section{RESULTS}

The mean diameter of the upper end was $2.8 \pm 0.5 \mathrm{~cm}$, lower end $2.1 \pm 0.4 \mathrm{~cm}$ and mid-HIVC $1.7 \pm 0.4 \mathrm{~cm}$. The upper diameter was significantly larger than the lower diameter $(p=0.001)$. The mid-diameter was found to be significantly smaller than the upper diameter $(\mathrm{p}=0.001)$ and the lower diameter $(\mathrm{p}=0.008)$. The mid-diameter was smallest in cases where the HIVC was completely enclosed by the liver $(1.6 \mathrm{~cm})$, and largest in cases where the HIVC ran in a shallow groove in the posterior surface of the liver $(1.8 \mathrm{~cm})$. In cases of incomplete tunneling, the mid-HIVC diameter was $1.7 \mathrm{~cm}$.

Generally, the HIVC was made up of three tunics; tunica intima, tunica media and tunica adventitia. The tunica intima was more prominent in the infrahepatic portion, consisting of a subendothelial fibroelastic zone and a few longitudinal muscle cell bundles. In the intrahepatic, the tunica intima was almost indistinct, while in the suprahepatic
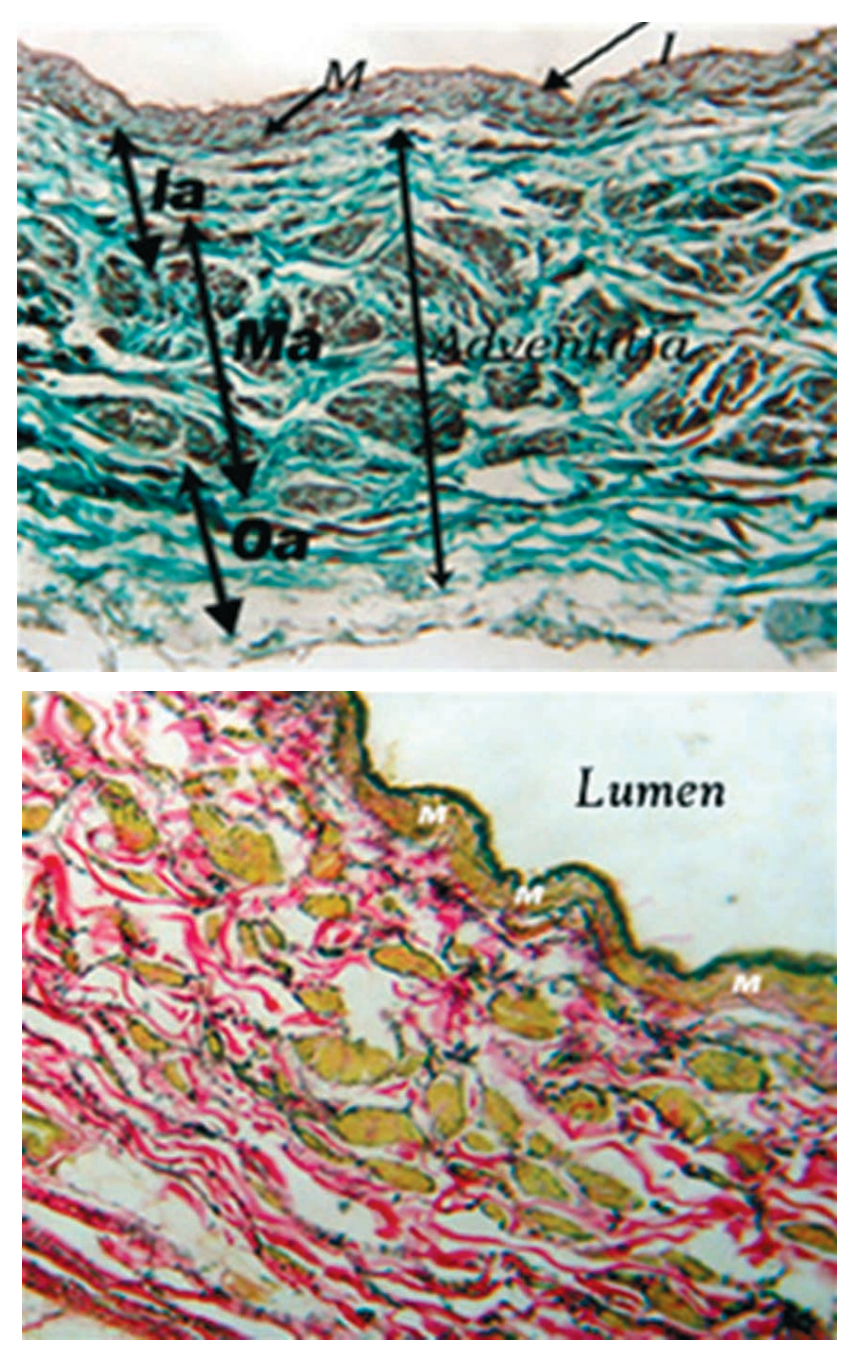

Fig. 2. Transverse sections of the HIVC wall showing the tunica intima (I), media (M), and adventitia (Adv). Note that the tunica adventitia is the thickest and has three zones (Ia, Inner adventitia; Ma, Middle adventitia; Oa, Outer adventitia). Fig 2a; Masson's Trichrome stain. X 100; 2b; Weigert's elastic with van Gieson counterstain. X100. 

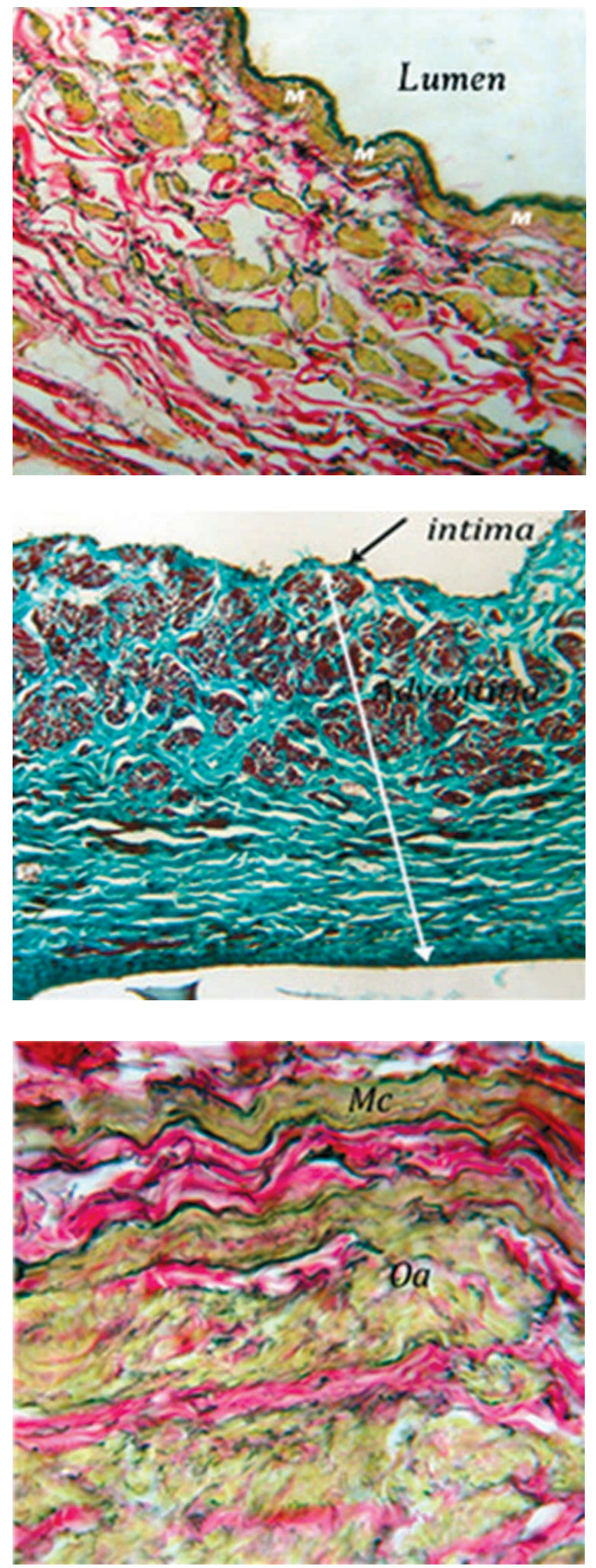

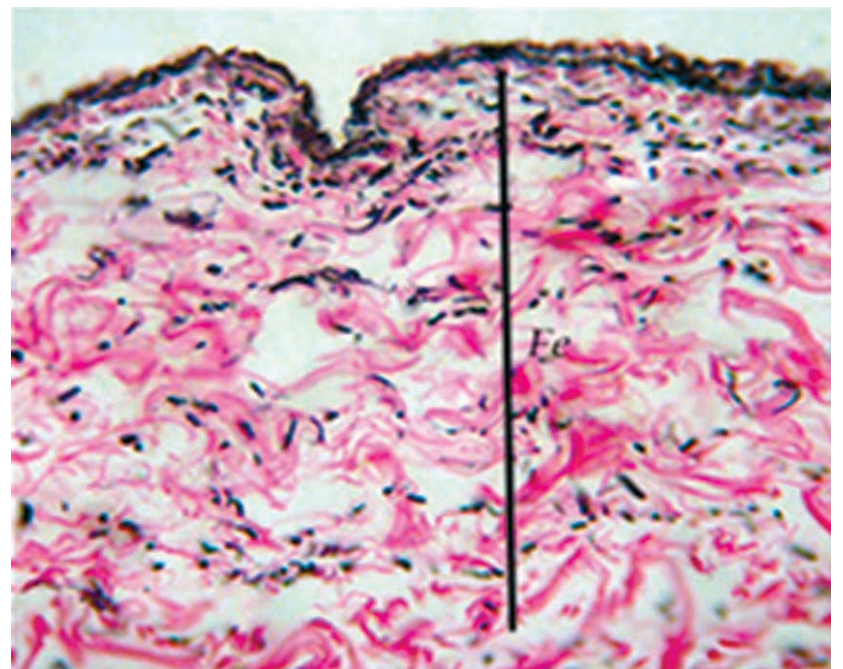

Photomicrographs of 3A; infrahepatic IVC showing a tunica media with circular smooth muscle fibers, 3B; the intrahepatic IVC with an intima and prominent muscular adventitia with no apparent tunica media, 3C; suprahepatic subphrenic IVC showing a tunica media with oblique muscle bundles and 3D; the suprahepatic phrenic portion showing a fibroelastic layer beneath the tunica intima with no apparent smooth muscle. 3A, C, D; Weigert's elastic stain with van Gieson counterstaining: X100, 3B; Masson Trichrome stain. X400. Note also that the tunica adventitia is the thickest layer and is more developed in the intrahepatic portion, and has paucity of muscle in the suprahepatic phrenic portion.

subphrenic and phrenic portions, it was made of haphazard elastic fibers.

The tunica media, the least developed tunic, comprised two to five layers of circularly oriented smooth muscle bundles separated by collagen-elastic fibers. There was no apparent tunica media in the intrahepatic portion, as the longitudinally disposed muscle of the tunica adventitia lay directly beneath the tunica intima. The suprahepatic subphrenic portion had a media comprising up to 3 layers of circular and oblique smooth muscle bundles. At the suprahepatic phrenic level, there was no distinct media as the whole wall was chiefly fibroelastic.

In three portions portions, the tunica adventitia was the most developed tunic with a three layer arrangement; an innermost zone of dense fibroelastic tissue, a middle muscular zone and an outermost fibroelastic zone. The muscular zone consisted of longitudinally oriented muscle fiber bundles which were separated by collagen septa. The tunica adventitia in the infrahepatic portion consisted of the three zones, with the muscle bundles loosely arranged. In the intrahepatic portion, only two zones were observed; an inner muscle layer and an outer fibroelastic zone. The muscle bundles were compact and bundle. The suprahepatic 
subphrenic IVC had large longitudinal bundles of smooth muscle. At the phrenic level, the whole wall was fibroelastic with paucity of smooth muscle. The outermost zone comprised loose areolar and adipose tissue surrounded by the tendon of the thoracic diaphragm.

\section{DISCUSSION}

In the present study, the mean diameter of the upper end of the HIVC was $2.8 \mathrm{~cm}$. This agrees with the general range of $1.9-4.0 \mathrm{~cm}$ and $2.5-4.0 \mathrm{~cm}$ (Nakamura \& Tsuzuki, 1981; Hirai et al., 2003). The table below summarizes the diameters reported for various populations.

Differences in diameter may be attributable to methodological differences (Chang et al., 1989), but actual population differences may also exist (Sahni et al.). The mean diameter of the lower end was $2.1 \mathrm{~cm}$; significantly lower than that of the upper end. There is limited literature on the lower end diameter. It is probable that the bigger diameter of the upper end is designed to accommodate additional blood from the hepatic system, through the hepatic veins which open mainly near the upper end.

The diameter of the mid-point between the upper and lower ends was significantly lower than the upper $(\mathrm{p}=0.001)$ and lower ends $(\mathrm{p}=0.008)$. This implies that the IVC, in its intrahepatic course, passes through a "bottle-neck." This is hitherto unreported in the HIVC. Similar constrictions have however been reported in human spinal radicular veins where they pierce the dura (van der Kuip et al., 1999). This has been proposed to constitute an antireflux mechanism; since the decrease in intravascular diameter will increase resistance and reduce blood flow. This proposition is supported by our observation that major hepatic veins open superior to the constriction.

This study confirms the findings of previous workers that the tunica intima has an endothelium, subendothelial connective tissue and smooth muscle bundles (Greep \& Weiss; Medeiros de Mello et al.). This organization is thought to contribute to vascular flexibility, and circumferential distension (Crissman et al., 1980; Zezula-Szpyra \& Grzegorewski, 2000; Caggiati et al., 2000). The absence of a thick subendothelial zone, internal elastic lamina and smooth muscles in the tunica intima of the intrahepatic makes it less compliant, thus facilitating sphincteric role.

The tunica media is the thinnest layer made of circular smooth muscle as reported by Greep \& Weiss. Circular smooth muscle plays a sphincteric role (Todd et al., 1983). With increased hemodynamic forces, circular smooth muscle changes orientation and migrates to the tunica adventitia (Greep \& Weiss). This may explains our observation of an indistinct tunica media in the intrahepatic portion.

The tunica adventitia was the thickest layer in the IVC. The predominantly longitudinal orientation of smooth muscle is an adaptation for propulsion of blood against gravity (Medeiros de Mello et al.). The presence of a more robust tunica adventitia, with more vasa vasora in the intrahepatic portion suggests increased hemodynamics and metabolic activity (Chuncher \& Somana, 2005). At the phrenic level, there was paucity of smooth muscle with the wall being mainly collagenous. Loose areolar and adipose tissue surrounded the tendon of the diaphragm. A dense diaphragmatico-pericardial tissue has been reported in rats and rabbits (Franklin, 1937). The paucity of smooth muscle may be explained by negative pressure in the IVC at the thoracic level. The connection between the IVC and the diaphragm ensures functional cooperation as has been reported elsewhere (Molinari et al., 1999).

In conclusion, the observation of a constriction inferior to the openings of major hepatic veins, a robust tunica adventitia in the intrahepatic portion and a tunica media in the infrahepatic portion allow us to propose that there exists a 'sphincteric mechanism' to prevent backflow of blood in the HIVC.

Table I. Comparison of morphometry of the HIVC in the present study and past workers.

\begin{tabular}{lcccc}
\hline Author and population & $\mathrm{n}$ & \multicolumn{3}{c}{ Diameter (cm) } \\
\hline Nakamura et al. (1981); Japanese & & Upper & Lower & Mid \\
Chang et al. (1989); Chinese & 83 & 2.5 & ---- & ---- \\
Camargo et al. (1996); Brazilian & 60 & 1.8 & ---- & ---- \\
Mehran et al. (2000); N.Amer. Canadian & 30 & 1.7 & ---- & ---- \\
Sharma et al. (2001); Indian & 30 & 1.8 & ---- & ---- \\
Sahni et al. (2006); Indian & 100 & 3.0 & ---- & ---- \\
Bundi et al. (2007); Present study & 500 & 1.9 & 1.8 & ---- \\
\hline
\end{tabular}


BUNDI, P. K.; OGENG'O, J. A.; HASSANALI, J. \& ODULA, P. O. Histomorfometría regional de la vena cava inferior hepática; un posible mecanismo de esfínter. Int. J. Morphol., 27(3):849-854, 2009.

RESUMEN: Este estudio tiene por objetivo identificar los cambios en el diámetro y la composición estructural de la vena cava inferior hepática en sus porciones infrahepática, intrahepática y suprahepática. Ochenta hígados de especímenes adultos de los depósitos de cadáveres de la ciudad de Nairobi y Chiromo fueron usadas para morfometría, mientras que veinte de ellos fueron procesados para microscopía de luz. Se observó una constricción en el medio de la HIVC, mientras que estructuralmente, la porción intrahepática había una gruesa adventicia fibromuscular. Es posible que este sea un aparato esfinteriano para evitar el reflujo de sangre en la vena cava inferior hepática.

PALABRAS CLAVE: Vena cava inferior; Hepática; Esfinteriana; Reflujo.

\section{REFERENCES}

Bancroft, J. D. \& Stevens, A. Connective tissues and stains. In: Theory and practice of Histological techniques. United Kingdom, Churchill Livingstone, 1994. pp.12934.

Caggiati, A. Fascial relations and structure of the tributaries of the saphenous veins. Surg. Radiol. Anat., 22:191-6, 2000 .

Camargo, A. M.; Texeira, G. G. \& Ortale, J. R . Anatomy of the ostia venae hepaticae and the retrohepatic segment of the inferior vena cava. J. Anat., 188:59-64, 1996.

Chang, R. W. H.; Shan-Quan, S. \& Yen, W. W. C. An applied anatomical study of the ostia venae hepaticae and the retrohepatic segment of the inferior vena cava. J. Anat., 164:41-7, 1989.

Cheng, C. P.; Herfkens, R. J. \& Taylor, C. A. Inferior vena caval hemodynamics quantified in vivo at rest and during cycling exercise using magnetic resonance imaging. Am. J. Physiol. Heart Circ. Physiol., 284: H1161-7, 2003.

Chuncher, S. \& Somana, R. Types of vascular wall as related to vasa vasorum in common tree shrew (Tupaia Glis). Microsc. Res. Tech., 67:317-24, 2005.

Crissman, R. S.; Ross, J. N. \& Davis, T. Scanning electron microscopy of an elastic fiber network which forms the internal elastic lamina in canine saphenous vein. Anat Rec., 198(4):581-93, 1980.

Franklin, K. J. A Monograph on veins. Springfield, Ill. Charles C. Thomas, 1937.

Greep, R. O. \& Weiss, L. Histology. $3^{\text {rd }}$ Ed. New York, McGraw- Hill Book Company, 1973. pp. 241-3.
Hirai, I.; Gen, M.; Wataru, K.; Kanamura, T. \& Sato, I. How should we treat short hepatic veins and paracaval branches in anterior hepatectomy using the hanging maneuver without mobilization of the liver? An anatomical and experimental study. Clin. Anat., 16:22432, 2003.

Mehran, R.; Schneider, R. \& Franchebois, P. The minor hepatic veins: anatomy and classification. Clin. Anat., 13:416-21, 2000.

Medeiros de Mello, J.; Piffer, C. R.; Orsi, A. M. \& Eleuterio, M. L. Structure of the vena cava caudalis of the dog (Canis familiaris). Rev. Chil. Anat., 15:45-50, 1997.

Molinari, S. L.; De Miranda Neto, M. H.; Chopard, R. P. \& Didio, L. J. A. Meso and microscopic study of the facial vein and adjacent tissues. Rev. Chil. Anat., 17(1):33-7, 1999.

Nakamura, S. \& Tsuzuki, T. Surgical anatomy of the hepatic veins and the inferior vena cava. Surg. Gynecol. Obstet., 152:43-50, 1981.

Sahni, D.; Chawla, H. Y. K. \& Jit, I. Gross anatomy of the retrohepatic segment of the inferior vena cava in northwest Indians. Indian J. Med. Res., 124:63-70, 2006.

Sharma, D.; Deshmukh, A. \& Raina, V. K. Surgical anatomy of the retrohepatic inferior vena cava and hepatic veins: a quantitative assessment. Indian $J$. Gastroenterol., 20(4):136-9, 2001.

Todd, M. E.; Laye, C. G. \& Osborne, D. N. The dimensional characteristics of smooth muscle in rat blood vessels. A computer assisted analysis. Circ. Res., 53:319-31, 1983. 
BUNDI, P. K.; OGENG'O, J. A.; HASSANALI, J. \& ODULA, P. O. Regional histomorphometry of the hepatic inferior vena cava; a possible sphincteric mechanism. Int. J. Morphol., 27(3):849-854, 2009

van der Kuip, M.; Hoogland, P. V. \& Groen, R. J. Human radicular veins: Regulation of venous reflux in the absence of valves. Anat. Rec., 254:173-80, 1999.

Young, B. \& Heath, J. W. Wheater's functional histology; a text and color atlas. $4^{\text {th }}$ Ed. London, Churchill Livingstone, 2002. p.155.

Zezula-Szpyra, A. \& Grzegorzewski, W. Morphology of the dorsal nasal, frontal and facial veins in adult gilts. Folia Morphol., 59(3):179-91, 2000.
Correspondence to:

Bundi Paul Karau

Department of Human Anatomy

University of Nairobi

P.O.BOX 30197-00100

Nairobi

KENYA

Email: pbkarau@gmail.com

Received: 12-02-2009

Accepted: 28-07-2009 